\title{
DO PINCEL AO PIXEL: ARTE, COMUNICAÇÃO E A SÉRIE BICHO DA SEDA, DE DELSON UCHÔA
}

\author{
FROM PAINTBRUSH TO PIXEL: ART, COMMUNICATION \\ AND THE BICHO DA SEDA SERIES, BY DELSON UCHÔA
}

DE PINCEL A PINCEL: ARTE, COMUNICACIÓN Y

LA SERIE BICHO DA SEDA, DEL DELSON UCHOAA

Ana Beatriz Bezerra de MELO

\section{RESUMO}

Este artigo é um desdobramento dos estudos no Programa de Pós-Graduação em História da Universidade Federal de Alagoas (UFAL), no periodo de 2015-2016. O objetivo geral deste artigo é apontar que como membro da 'Geração 80' em Alagoas, o artista Delson Uchôa continua alimentando a História da Arte através de novas perspectivas com o uso das mídias digitais. A metodologia utilizada foi uma entrevista semiestruturada, realizada no período do trabalho dissertativo com o artista e estudos bibliográficos em fontes como livros e periódicos da década estabelecida. Os resultados indicaram que as reflexões sobre as obras do artista Delson Uchôa, especificamente na série Bicho da Seda, envolvem observações sobre o processo produtivo do artista, seu cultivo de obras e sua relação com as mídias digitais que atinge a sociedade de massa e se adequa a sua linguagem através da comunicação em rede.

\section{PALAVRAS-CHAVE:}

Geração 80; Mídias Digitais; Cultura Contemporânea.
ABSTRACT

This article is an outcome of the studies in the Post-Graduation Program in History of the Universidade Federal de Alagoas (UFAL), from 2015 to 2016. The main goal is to point out that as a member of 'Generation 80' in Alagoas, the artist Delson Uchôa continues to feeding Art History through new prospects with the use of digital media. The methodology used was a semistructured interview, carried out in the period of the dissertative work with the artist and bibliographical studies in sources such as books and periodicals of the established decade. The results indicated that the reflections on the works of the artist Delson Uchôa, specifically in the series Bicho da Seda, involve observations about the artist's production process, his cultivation of works and his relationship with digital media that reaches mass society and is appropriate to language through network communication.

\section{KEYWORDS:}

Generation 80; Digital Media; Contemporary Culture.
RESUMEN

Este artículo es una parte de los estudios en el Programa de Posgrado en Historia de la Universidad Federal de Alagoas (UFAL), de 2015 a 2016. El objetivo general de este artículo es señalar que, como integrante de la 'Generación 80' en Alagoas, el artista Delson Uchôa continúa fomentando la historia del arte a través de nuevas perspectivas con el uso de medios digitales. La metodología utilizada fue una entrevista semiestructurada, realizada durante el trabajo de tesis con el artista y por medio de los estudios bibliográficos en fuentes como libros $y$ publicaciones periódicas de la década establecida. Los resultados indicaron que las reflexiones sobre las obras del artista Delson Uchôa, especificamente en el seriado Bicho da seda, involucran observaciones sobre el proceso de producción del artista, su cultivo de obras y su relación con los medios digitales que llegan hacia la sociedad y son apropriados a su idioma a través de la comunicación en red.

PALABRAS CLAVE:

Generación 80; Medio Digitale; cultura Contemporánea. 


\section{INTRODUÇÃO}

A História da Arte brasileira e o uso das mídias constitui parte da dinâmica presente na Arte Contemporânea. Neste sentido, Delson Uchôa se apresenta como um pintor alagoano fruto da 'Geração 80' brasileira, cuja atuação pode ser comprovada na mostra Como vai você, geração 80?, ocorrida em 1984 no Parque Laje, Rio de Janeiro. Seu caminho de aprendizado na pintura, conforme Melo (2016), é diversificado: foi aluno no atelier do pintor Pierre Chalita, em 1980, e formou-se em medicina pela Universidade Federal de Alagoas, na turma de 1981. Construiu sua base curricular personalizada e, com esse perfil diferenciado, estabeleceu a sua identidade nas artes plásticas.

Este artigo foi desenvolvido a partir de uma metodologia exploratória na área da História Cultural com o uso de fontes primárias como o jornal Gazeta de Alagoas e o extinto Jornal de Alagoas, encontrados ao longo de uma pesquisa em acervos públicos e privados. Em paralelo, uma entrevista semiestruturada foi realizada com o artista Delson Uchôa a fim de captar a fonte oral para a realização de inferências sobre o seu histórico e transformações artísticas.

Assim, o artista é localizado no período de ruptura na História da Arte, no Brasil com início em 1950. As vanguardas europeias desenvolveram as précondições que desencadearam, simultaneamente, a Arte PósModerna e Arte Contemporânea com a influência de movimentos pouco difundidos pelos críticos de arte como a Arte Povera, Body Art, Performance, Arte Contextual, dentre outros (CANONGIA, s.d.). As referências encontradas na obra do artista envolvem pintura, fotografia e objetos tridimensionais, também englobam o conceito de hibridização na arte (CANCLINI, 2015).

Uchôa em seu processo de trabalho produz obras vivas como quem busca a presença da arte sem limites. As cores reencarnam a pele de cada tela e desperta no receptor o desejo de enxergar para além da superficie (DIDI-HUBERMAN, 2012). Através das mídias digitais, o consumo destes aspectos da arte torna a experiência mais intensa, capaz de transitar em redes e dialogar com narrativas sonoras e verbais.

Nessa perspectiva,a comunicação e os ciclos artísticos estão convergindo na contemporaneidade. É uma aliada nas relações entre arte, artista e receptor. Delson Uchôa utiliza suas redes sociais Facebook (Delson Uchôa) e Instagram (@delsonuchoa)para expor seus trabalhos e momentos de criação. Na série Bicho da Seda, analisada neste artigo, suas peças foram criadas a partir de "sombrinhas" oriundas do mercado chinês, objetos produzidos em massa pela indústria e de fácil descarte, mas que nesta arte autoral conduz a narrativas inspiradoras e reconfigura sua função de objeto de proteção para objeto poético-artístico.

Na citada série, além de suas pinturas em larga escala, são utilizados objetos tridimensionais. $\bigcirc$ artista se deslocou para lugares remotos do interior de Alagoas $e_{1}$ fotografou as obras em meio a paisagens pouco exploradas, utilizando sua figura em alguns momentos como parte da performance artística. Sua arte é assim, uma espécie de pigmento utilizado para explorar o olhar fotográfico.

O PROCESSO ARTÍSTICO E SUAS RAÍZES: SUTURAS E TRANSFUSÕES NAS OBRAS DE DELSON UCHOAA

Uchôa possui formação em medicina pela Universidade Federal de Alagoas, em 1981, porém construiu sua grade curricular artística com início no atelier do pintor Pierre Chalita na década de 1980, em Maceió.

Assim, é através da arte que costura telas e objetos como a trama das cestas do artesanato alagoano além das cores e formas presentes na natureza, onde habita em seu ateliê mais afastado da cidade. Assim, ele encarna nas suas obras uma imagem de presença e não de representação

(DIDI HUBERMAN, 2012).

O artista expõe elementos da natureza, recorrentemente tematizada, em Maceió, pelas artes em suas obras, aproveitando-se das suas formas geométricas e expandindo a sua percepção sobre a realidade e a diversidade do seu olhar, por meio dos símbolos. Ele propõe novos espaços e mutações para a arte quando trabalha com o cultivo das suas obras, modificando-as frequentemente enquanto estão em seu domínio (Fig. 1)

Figura 1: Delson Uchôa e o processo artístico em seu ateliê.

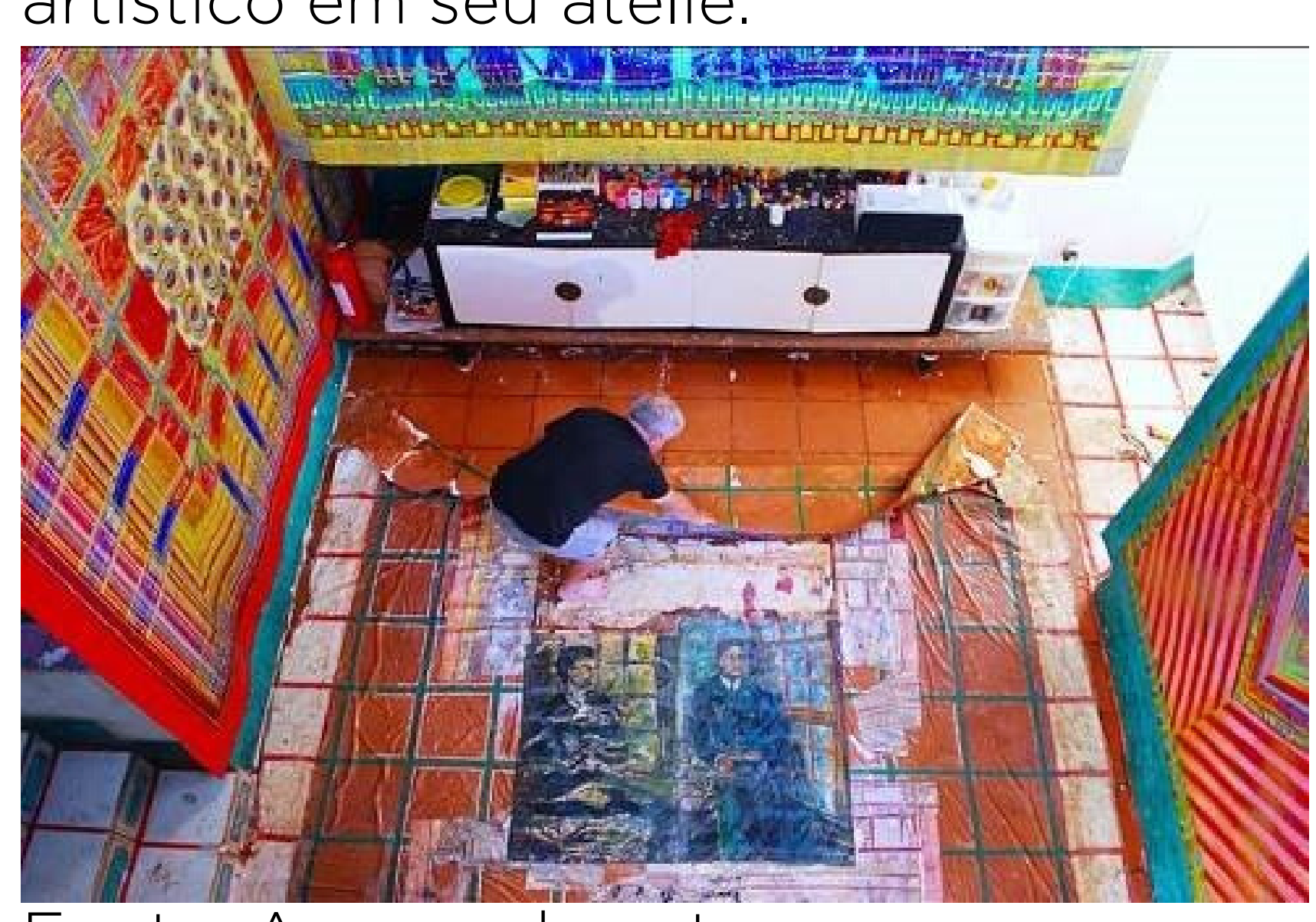

Fonte: Acervo da autora. 
São realizadas novas incisões de cores e texturas, em um processo frenético. As cores nas suas obras são iluminadas e constitui um dos elementos identitários na sua arte. O vermelho, por exemplo, é um vermelho encarnado, presente principalmente nos folguedos alagoanos, é uma cor viva. Diferente do vermelho europeu, denso, escuro atingindo a cor púrpura com muita facilidade (MELO, 2016).

Didi-Huberman (2012, p.37), na obra A Pintura Encarnada, levanta questões sobre a pintura ir além da pura visibilidade. A encarnação na pintura é uma condição para que os olhos se desviem, atravessem a superfície da tela e alcance o verdadeiro significado da obra. Para que ela esteja viva, é necessário que a pintura possa ser "imaginada como um corpo e como sujeito". O visível está, para o teórico, relacionado a idolatria e representação, enquanto o visual está além do visível, sendo uma imagem de presença.

A superfície da pintura é então, parte da origem da comunicação sendo a imagem um instrumento representativo, pois junto com as linguagens fazem parte de sistemas simbólicos utilizados pelo homem em sociedade.

\section{A 'GERAÇÃO 80' E A ESTRUTURA PÓS- MODERNISTA NA ARTE}

Delson Uchôa integra uma geração marcada pelo prazer da pintura. A 'Geração 80', como ficou reconhecida, promoveu o amor por esse gênero (embora não tenha sido o único praticado), sem amarras às correntes de vanguarda e à crítica da arte clássica.
Expandiu-se por várias cidades do país, incluindo Maceió, mas seu eixo foi Rio de Janeiro e São Paulo, com diferentes grupos de artes visuais: no Rio de Janeiro o da Escola de Artes Visuais (EAV) do Parque Laje e os grupos Casa 7 e Fluxus, em São Paulo.

Nessa perspectiva, Delson Uchôa manteve a coerência da sua proposta iniciada na icônica exposição "Como vai você, Geração 80?", em 1984 no Parque Lage (RJ). O artista chegou a se engajar inclusive no debate público, na campanha de 1986 em Maceió, quando integrou o grupo que defendeu uma candidatura de esquerda, do então candidato ao governo Ronaldo Lessa, no projeto "Uma campanha com arte". Criada para difundir a política como proposta também estética, com a difusão de pinturas vanguardistas em outdoors, ao invés de utilizar a clássica foto do candidato (GAIA, 1986).

Na História da Arte, esse momento gerou críticas por constituir-se de expressões artísticas pouco exaltadas nos círculos da grande crítica artística, como a Arte Povera italiana, Arte Conceitual, Process Art, Bad Painting e o Minimalismo, unidos também aos Happenings. Para compreender este contexto, é relevante fazer a distinção entre os termos que envolvem o Modernismo e o PósModernismo.

Neste sentido, Charles Baudelaire se apresentou como um dos o porta-vozes do termo Modernidade, a partir do terceiro quartel do século XIX. O termo define o que passa a ser efêmero e contingente na arte, esta seria uma das partes; a outra é dada pelo que há de imutável e perene
(BAUDELAIRE, 1996). O homem moderno, conforme indicou o teórico, deveria adequar-se à modernidade e reforçar a tradição e a memória para garantir sua contribuição a partir dos elementos característicos temporalidade.

A transitoriedade, em marcostemporais, caracterizou a divisão entre $\mathrm{o}$ antigo e o novo, portanto, é válido distinguir "Modernidade" de "Modernismo". A Modernidade é constituída pela transformação do social como reflexo do mundo industrial. A partir do século XIX torna-se um momento ambíguo, pois, ao mesmo tempo em que apresentava, por exemplo, o aumento na produção industrial, por outro lado, aumentava a miséria na parcela menos favorecida da população. Já o Modernismo está associado aos movimentos artísticos que se expandem durante todo o século XX (VELLOSO, 2010).

Esta divisão encontrou um período de inflexão com a emergência do Pós-Modernismo que garantiu novas possibilidades da arte em sua técnica, teoria e crítica, a partir de novos questionamentos. O artista Delson Uchôa, integrou uma geração cuja trilha permite o registro do conhecimento histórico relevante no estudo das imagens na história, principalmente em um país como o Brasil, onde a cultura do esquecimento é evidenciada pelas lutas de poder. A 'Geração 80' passa a ser uma dessas constatações, na medida em que a Arte Contemporânea, que se manifesta a partir dos anos 1950, recria novas possibilidades integrando arte e vida, de modo simultâneo.

O início da década de 1980 foi 
marcado por fatos históricos em prol de uma renovação ideológica como a explosão de uma bomba no RioCentro (Rio de Janeiro, 1981), em uma tentativa de bloquear o processo de abertura política no país. Em um processo de redemocratização, o Brasil sai progressivamente de um regime ditatorial para as campanhas das Diretas Já, em 1984. Ricardo Basbaum, artista e crítico brasileiro, declarou que:

Poucos artistas tinham plena consciência da influência da distensão pós-ditadura em suas obras, afirma, por outro lado, que eles eram vistos como aqueles jovens que trazem

redemocratização

política e a

liberação

de

comportamentos e

costumes'. Dessa

forma, percebia-se claramente a conexão entre a estética desconstruida e espontânea da arte nacional naqueles primórdios dos anos 80 e a nova ambiência política que aflorava (CANONGIA, s.d., p. 26).

A Pós-Modernidade, nos marcos desta pesquisa se apresenta como um sucedâneo da Arte Contemporânea e do Contemporâneo, tornando-se, assim, uma temporalidade sujeita a polêmicas, mas constitutiva de uma estrutura que estabelece 0 terceiro momento do capitalismo, o capital globalizado. Em razão da capilaridade do mercado global, das redes de comunicação, do uso de tecnologias, nas suas mais distintas modalidades e, assim por diante. É uma revolução cultural a ponto de reprogramar todas as pessoas para fazer parte do novo sistema (JAMESON, 2015).

Segundo Canclini (2015), ao centralizar o estudo nas artes plásticas, demonstra-se a perda de autonomia da elite. Boa parte do que circula pelas indústrias culturais, eram patrimônio das elites, como elemento distintivo. Aponta ainda que para um artista trabalhar em torno da cultura popular e dos meios massivos faz-se necessária a condição de uniqüidade em que imagens são utilizadas como um conjunto de signos cujo significado é mutável a depender do contexto da sua obra. Assim, a arte desempenhada a partir da 'Geração 80' e suas repercussões, possui um papel significativo para a democratização da cultura e transformação do conceito de cultura.

A certeza de um novo momento na arte, eclode no ano de 1980 com a inauguração da seção Aperto 80 na Bienal de Veneza, por Harald Szeemann [19332005] e Achille Bonito Oliva [1939-] cujas influências também estiveram presentes na exposição Como vai você, Geração 80?, em 1984, na cidade do Rio de Janeiro (RJ).

Delson Uchôa é um dos integrantes dessa geração e leva para o Parque Laje (RJ), um híbrido (Fig. 2) em larga escala, repleto de signos definidos como "aquilo que dá corpo ao pensamento, às emoções, reações etc. Por isso mesmo, pensamentos, emoções e reações podem ser externalizadas" (SANTAELLA, 2004, p. 10), pois remetem ao seu lugar de pertencimento e, naquele momento, os artistas apresentavam indicativos de que a nova cena artística se instaurava com aspectos nômades e hedonistas.

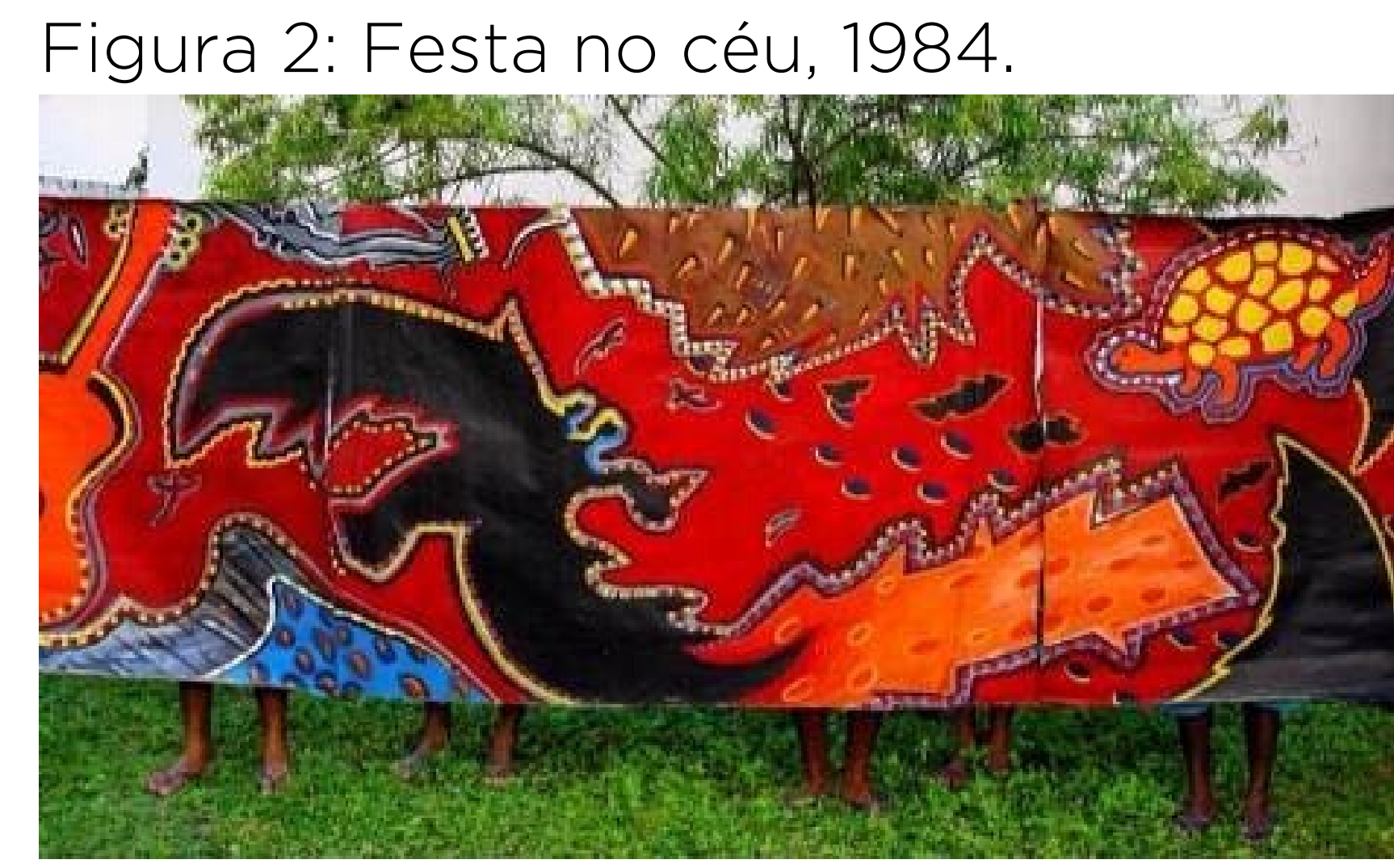

Fonte: Acervo da autora.

O resultado dessa nova prática foi o uso indiscriminado de diferentes recursos usuais da arte moderna. Até a contemporaneidade, a arte pictórica se posicionou na história de modo

híbrido,seguindo um mix de interferências. Foram ignoradas as distinções teóricas entre modo artístico progressista e/ou conservador. Os movimentos artísticos anteriores serviram como uma antessala para a 'Geração 80' uma vez que, $\quad$ Pós-Modernismo encontra na década o ponto de tensão de conflitos entre as teorias Pós-Modernistas. (CANONGIA, s.d.).

Para compreender os caminhos da Arte Contemporânea presentes nos trabalhos de Delson Uchôa e reconhecer sua art como parte das representações culturais brasileiras, é válido entender estas referências de símbolos e signos que imprimiu ao longo da sua trajetória e da sua rede de relações e conhecimentos, o que resultou na (re)aproximação da Arte com a Comunicação.

O desejo do artista era transformar o seu trabalho na representação da identidade e da diversidade das suas raízes, pois a sociedade e todo o seu sistema sempre estiveram diretamente relacionados ao trabalho artístico. Conforme indica Pitta (2007, p. 136-37) 
quando se elabora a representação de uma forma, não se pode separa a sua função, considerando "as exigências da sociedade onde aquela determinada linguagem visual é válida. Toda mudança de função da arte ocasionaria, portanto, uma mudança de forma, e assim, de estilo". Além disso, nessa mesma perspectiva, quando se altera a função é necessário pressupor que decorrem daí novas cobranças e uma mudança também no comportamento de quem recepciona a obra.

As imagens artística contribuem para a representação cultural, "construída através de formas simbólicas" (CHARTIER, 1987, p. 17) e sua problemática pode ser moldada pelo discurso, em forma de texto ou imagem, fio condutor para a base de reflexões sobre o real e o atual. Através da cultura de massa e seus meios de comunicação, identifica-se nas artes plásticas um terreno fértil para as lutas de representações, composições dos campos sociais e a legitimação simbólica de aspectos que reformulam ou justificam os próprios indivíduos.

\section{DELSON UCHÔA, AS MÍDIAS DIGITAIS E A SÉRIE BICHO DA SEDA}

Refletir a respeito do fragmento para a recomposição do híbrido, de acordo com Rancière (2009) desfaz a ideia de representação para indicar ao inconsciente que não se trata de uma história individual, mas o figurativo sob o visivel representado. A exposição artística por meio das mídias digitais provoca questões quanto a espetacularização da produção artística e revisa o artista como o gerador de signos culturais na recodificação da informação.
Didi-Huberman (2013), explora a relação da imagem obra-real e imagem obra-midiatizada quando questiona o lugar da imagem na História da Arte que sempre foi um estudo voltado à exatidão, para a descrição de uma verdade que não pode ser compreendida como absoluta. - autor revela a constante construção da história da imagem com base na informação circular em uma rede aberta, sem a ideia de fechamento existente na História da Arte.

Isso ocorre porque as artesforam pesquisadas por muito tempo como uma ocorrência no campo do visível, em um campo fechado. 0 exame crítico, em sua maioria, é fornecido e qualificado pelo mainstream, assim a midiatização da arte autoriza que tudo se torne visível e possa ser visitado a toda hora, de modo perene e atemporal.

Sobre esse ponto de vista, Santaella (2005) aponta a hipermídia como linguagem pós-moderna. É conceituada como o acesso simultâneo entre determinados textos, sons e imagens interagindo em um ambiente único digital. Possui um caráter fluido, submetido às intervenções do usuário e assim, constituindo-se em arquiteturas líquidas. Possui a capacidade de armazenar informações através da interação do receptor, posicionando-o como co-autor na interação.

É relevante uma reflexão sobre as diferentes mídias utilizadas na década de 1980, e as utilizadas hoje e como isso afeta - olhar sobre a arte. A 'Geração 80' em Alagoas teve como mídias anteriores a restrição entre jornais e reuniões presenciais, conforme entrevistas concedidas pelos artistas da época (MELO, 2016) Atualmente, todas as questões antes restritas a plataformas físicas e encontros datados se difundem em ambientes virtuais que possibilitam expandir (1) linguagens verbais e não verbais que comunicam ideias e sentimentos através de signos diversos (sonoros, visuais, gráficos, $\quad$ gestuais);

narrativas que permitem sistematizar a forma de indicar o trajeto da própria obra e (3) discursos, processos contínuos que consideram as representações com base na sua materialidade, inseridos em um modo de produção capitalista que indica conflitos sociais e se situa em espaços de saberes e poderes.

Uchôa, na sua trajetória, tem se desprendido tanto dos limites das dimensões de tela quanto dos suportes, o que requer pensar um discurso híbrido capaz de construir sua própria narrativa a partir de linguagens alternativas, uma das suas marcas características, desde o lançamento de suas bases, no Parque Laje. As imagens hoje compartilhadas pelo artista em suas redes sociais, integram uma nova mídia para a pintura. Suas obras esféricas da série Bicho da Seda, por exemplo, compõem um pigmento para a imagem digital (Fig. 3).

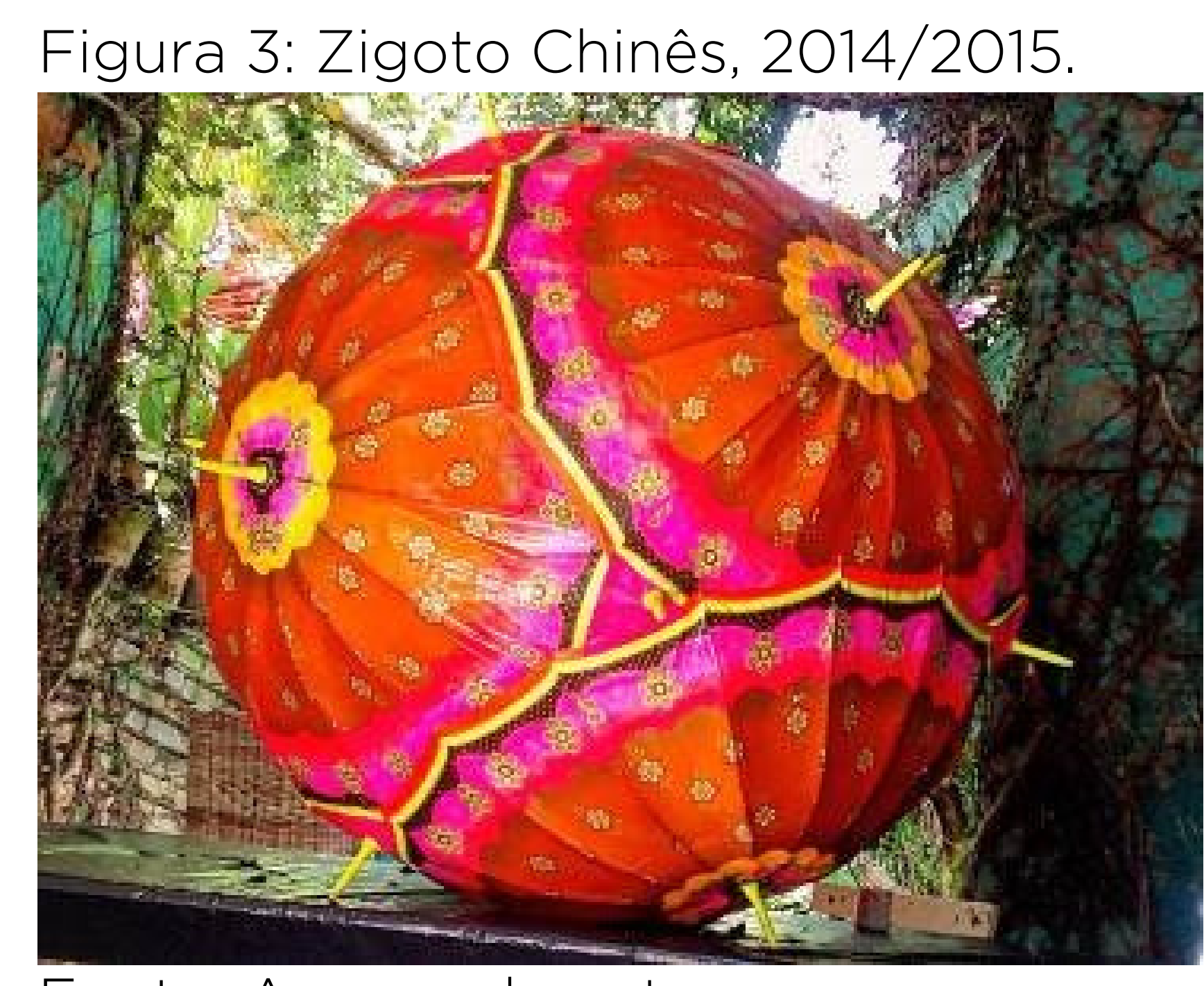

Fonte: Acervo da autora.

Ocorre nesta série a ressignificação de um objeto / elemento (as sombrinhas) 
produzido em alta quantidade pela indústria, Made in China oriundas do trabalho escravo. Essa narrativa é reveladora do poder de catarse na obra, partilhada entre a arte e a vida. Sua obra provoca discussões, estranhamentos e conduz a diferentes interpretações devido à manifestação de signos multifacetados (VIEIRA, 2015). Em outras palavras, o Bicho da Seda é transfigurado em satélite, em radar.

Desse modo, a arte, bem como o artista, são sujeitos sociais transformadores quando transmitem indicadores de novos pensamentos, paradigmas e contrastes em formas simbólicas. Uchôa, posiciona suas criações em diálogos políticos quando propõe narrativas artísticas sobre a globalização, mercado de arte e sustentabilidade.

O artista Delson Uchôa é um nome proveniente da geração que continua a provocar com sua arte. A 'Geração 80', permanece entregando à sociedade novas discussões e olhares da arte através do objeto virtual, redes interativas e com atualizações constantes que estendem os limites entre o território físico-geográfico. Sobre essa questão, Braga (2015, p. 21) indica que a série Bicho da Seda ao apresentar as sombrinhas fabricadas na China, impõem ao mesmo tempo um discurso de alteridade e também de plasticidade, pois "colocam cores e padronagens decorativas na paisagem seca da caatiga alagoana".

Quando aproxima essas imagens de poços de água, por exemplo, lança uma metalinguagem narcísica. Além disso, a inserção de um elemento industrial e sintético sintético na paisagem arenosa sertaneja, provoca uma necessária reflexão sobre os pontos dissonantes da obraproduto. É preciso considerar que "as sombrinhas são assustadoramente baratas, produzidas à custa de baixíssimos salários e alto impacto ambiental. Para além da superfície colorida, o belo da matéria chega a um discurso político" (BRAGA, 2015, p. 21).

A ênfase de Uchôa em seus trabalhos é a pintura que indica um trajeto para além dos sentidos táteis quando faz uso da imagem para postagem nas mídias digitais. A virtualização, conforme explicou Lévy (1996), acarreta a frequência no processo de materialização, expande sentimentos contraditórios como a fragilidade e desgaste versus controle e segurança.

Walter Benjamin, na sua discussão sobre a Era da Reprodutibilidade Técnica, apontou o cinema como uma técnica de difusão massiva mais eficaz que a pintura (JIMENEZ, 1999). Hoje com as mídias digitais, no entanto, outra reflexão se faz necessária, pois a dinâmica entre a fotografia e o vídeo transforma a experiência e a comercializa. A mídia, portanto:

É melhor entendida como um sistema controlando recursos de informação apreciados e escassos que gerem relações interdependentes com outros sistemas, relacões essas que produzem cooperação motivada pelo interesse mútuo, conflito motivado pelo interesse próprio, e mudanca para maior simetria ou assimetria da dependência (DEFLEUR; BALLROKEACH, 1993, p 340).

No entanto, não significa a configuração de algo imaterial ou fugaz porque uma obra de arte, como destacou Lévy (1996, p. 37) indica, ao mesmo tempo, aspectos sobre o que poderá ser e do que virtualmente configura, já que pode ser tanto um signo que indica prestígio ao seu autor, como pode apresentar-se com sua aura, mas também ter valor mercantil. Os discursos que estão inseridos em uma obra de arte contemporânea ampliam suas complexidades, já que pode revelar-se como "portador de uma imagem a interpretar, de uma tradição a prosseguir ou a contradizer,

enquanto acontecimento na história cultural".

Considera-se uma expansão do olhar. E ao mesmo tempo em que transmuta a representação de uma imagem e a eterniza, provoca uma perda. DidiHuberman (1998) retoma esta questão quando propõe direcionar a visão para o não visto de maneira evidente. Ao manifestar o sentimento a partir do objeto e sua imagem considerando apenas a visão, a percepção se esvai.

A inserção das artes no ciberespaço, mais precisamente nas redes utilizadas como meio de intercomunicação entre dispositivos online, que resulta em comunicação entre homemmáquina, provoca frequência no processo de materialização. Existe ao mesmo tempo troca de informações e de saberes, independente de posicionamentos geográficos ou sociais. A tecnologia é produzida a partir da mão 
humana como artífice e o artista transforma os espaços com seu posicionamento político e ações instigantes que transmutam para a representação social e cultural.

As obras da série Bicho da Seda apresentam um discurso que transita entre a arte, a globalização e a ecologia (Fig. 4). Nas mãos do artista, objetos como sombrinhas descartáveis são tratados como pigmentos e o modo de execução dos seus trabalhos se destaca dos seus primórdios até a contemporaneidade, pois a narrativa é composta por uma espécie de performance virtual.

Figura 4: Instalação da série Bicho da Seda, 2012

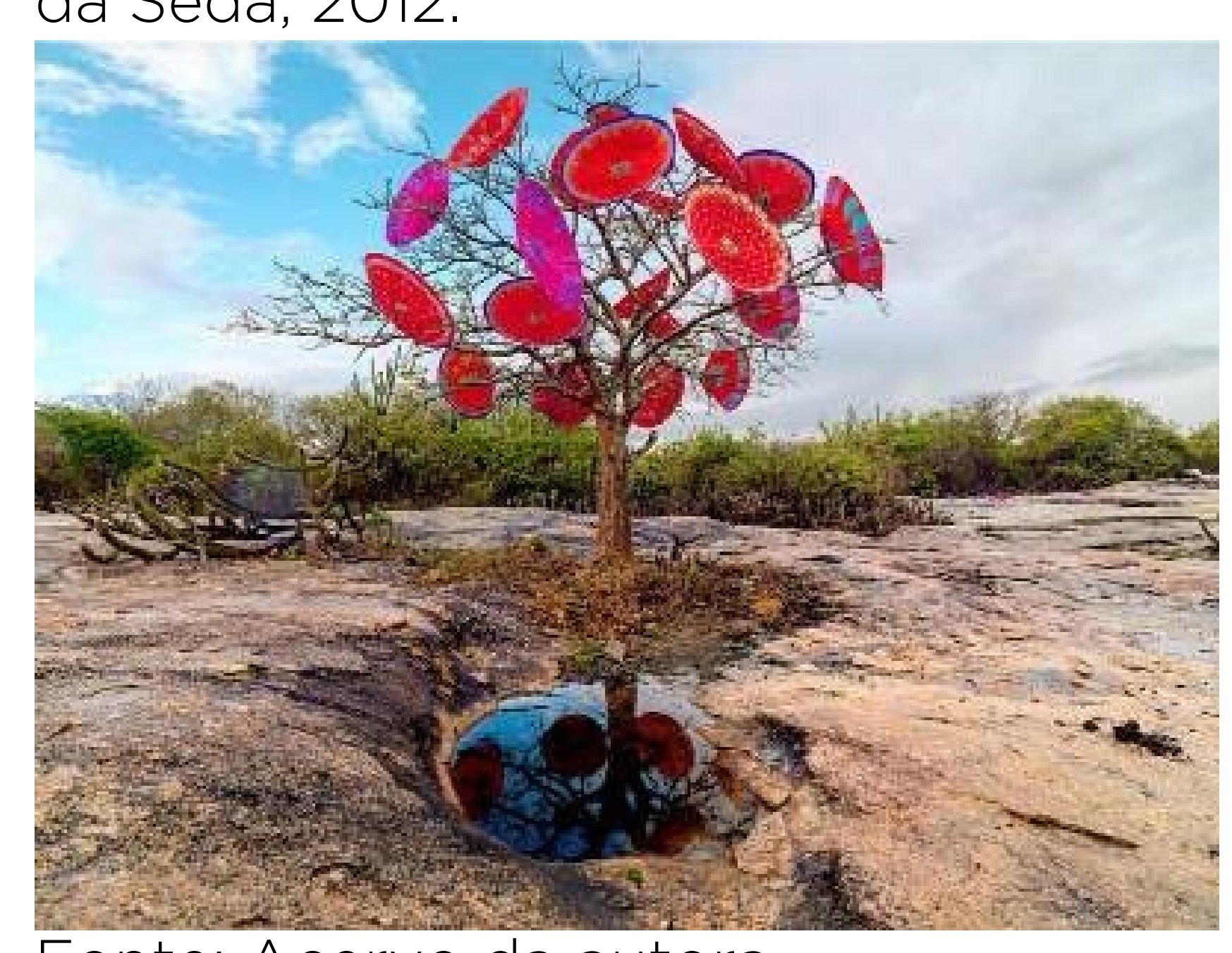

Fonte: Acervo da autora.

A própria figura do artista também integra a fotografia, através de movimentos que remetem ao folclore artístico alagoano, e assim a presença do artista na obra transforma e subverte a representação em algo concreto no virtual.

Sobre a série, Uchôa reconfigura a expressão da sua identidade com seu histórico de vida local, do nordeste brasileiro (Fig. 5). Sua pintura, se expande sobre Ionas, esteira, plásticos e outros materiais que concentram marcas e cores, em um processo de acúmulo de memórias através do empirismo. As cores e a luz das tramas constituídas em seu trabalho, na região em que mora, cria aspectos simultâneos entre o popular e o cosmopolita (DIEGUES; COELHO, 2012).

Figura 5: Azul Maria, entre o céu e a terra. Da Série Bicho da Seda, 2014

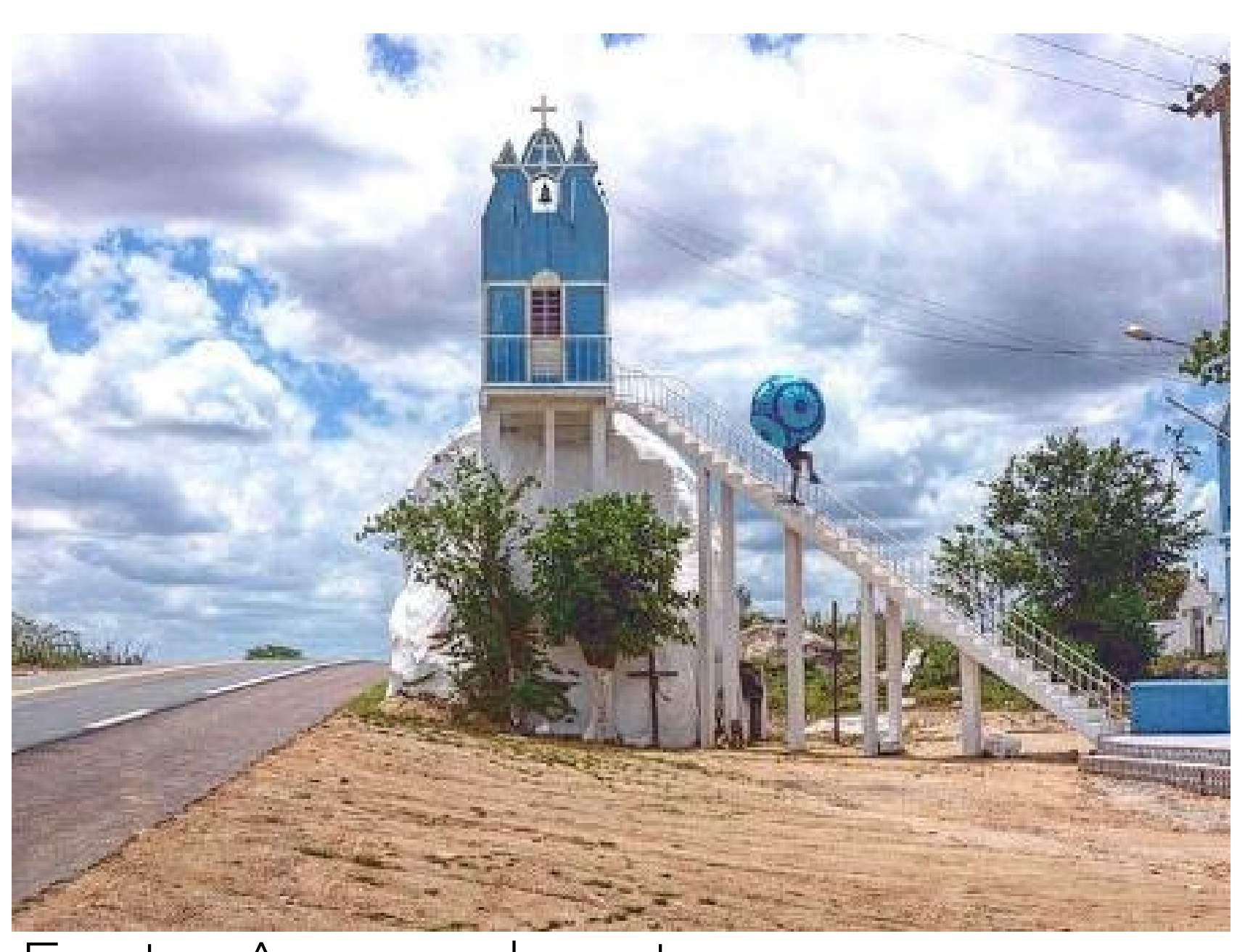

Fonte: Acervo da autora.

Ao analisar este ato, é como se para o artista, assim como foi para o fotógrafo Henri CartierBresson, a pintura tenha contribuído para sua aprendizagem no modo de enxergar a fotografia (CARTIERBRESSON, 2015). Nesse sentido, Uchôa tem expandido a presença do seu olhar a cada manifestação/publicação dos trabalhos que realiza.

Este processo posiciona o artista em uma representação de presença concreta através da comunicação de massa nas mídias digitais. O sujeito como objeto cultural e social utiliza o seu repertório histórico, repleto de memórias para transmitir e produzir sentidos. Assim, a manifestação dos signos artísticos pelas mídias tecnológicas constrói novos sistemas de cultura e assim o artista ressalta os caminhos mutáveis na História da Arte e participa dela como produtor de conhecimento, através da criação coletiva existente na cultura de massa.

\section{CONSIDERAÇÕES FINAIS}

Toda a forma de condução traduz e altera o transmissor, o receptor e a mensagem. E através dos meios de comunicação de massa, utilizada por Delson Uchôa, a experiência nestas relações são aguçadas com imagens estáticas e em movimento e, em um continuum ressignificar, pautado pelo hibridismo cultural, nas suas transmutações frequentes.

Na série Bicho da Seda Delson Uchôa trabalha com questões políticas sem abandonar narrativas poéticas. $O$ artista, através das suas obras, compõe representações que permeiam suas experiências em um dado momento histórico. Assim, contribui para as representações culturais ao aplicar elementos simbólicos nas suas obras e assim, suas telas adquirem significados para além da superfície.

O virtual agrega novos sentidos, transforma e perpetua a produção artística, uma vez que novas interações e atos como o de copiar e colar renova os signos híbridos. Os signos artísticos são massificados e conectados em rede onde o receptor pode também expressar-se. As particularidades simbólicas são assim produtos sociais e parte da história, mas para entendelos é preciso conhecer suas condições de produção e a sua memória, concedidas por Uchôa nas suas redes sociais.

O artista abre espaço para a criação de microredes em suas mídias sociais e uma participação criativa para aqueles que acompanham o seu conteúdo. As relações são mais diretas e a comunicação rápida e efetiva. O virtual, ao contrário do que já foi pensado anteriormente pela Teoria crítica, como algo apocalíptico e frágil, faz da história da imagem algo circular, aberto e com 
interações imediatas. Nesse sentido, desloca-se tambémpara uma leitura crítica e de posição política, ao contrário de uma lógica que indica aculturação.

A carne, lembrada através da cor vermelha em suas obras, faz das suas telas o tecido para suas costuras e transfusões enquanto a produção permanece em seu domínio. O olhar, sentido aguçado a princípio, passa a provocar o desejo de identificar a presença em um fragmento da natureza. Uchôa a cada pincelada e suturas, eleva os questionamentos sobre os limites da pintura.

A rede social faz do artista um sujeito presente e ativo capaz de assumir o papel de um agente, mediador, transformador do meio social. Posto que, por definição, a informação é um ato de transmutação, de transformação. A imagem de Delson Uchôa, além de representar as transformações de uma cultura material e simbólica reorganiza novas percepções, pois atinge a sociedade de massa quando adequa sua linguagem às novas tecnologias e à comunicação em rede.

Esta pesquisa identificou que Delson Uchôa compõe a História da Arte Pós-Moderna por ser um sujeito capaz de transmutar entre os signos constituintes de uma representação cultural e de narrativas poéticas propagadas em meios massivos capazes de integrar o imaginário coletivo social.
REFERE⿵NCIAS

BAUDELAIRE, Charles. IV A modernidade. In: COELHO,

Teixeira (Org.). Sobre a modernidade: o pintor da vida moderna. Rio de Janeiro: Paz e Terra, 1996. [Coleção Leitura]. p. 24-28.

BRAGA, Paula. Delson Uchôa: belo em si. São Paulo: Zipper Galeria, 2015

\section{CANCLINI, Nestor García.}

Culturas Hibridas: Estratégias para entrar e sair da modernidade. 4ed. São Paulo: Editora da Universidade de São Paulo, 2015.

\section{CANONGIA, Ligia. Anos 80:}

Embates de uma geração. Rio de Janeiro: Francisco Alves, s.d

\section{CARTIER-BRESSON, Henri. É} muito difícil fotografar.

entrevista com Richard L. Simon. In: CLÉMENT, Chéroux, JONES, Julie (org.). Ver é um todo: entrevistas e conversas. São Paulo: Gustavo Gili, 2015.

CHARTIER, Roger. A história cultural. Entre práticas e representações. Lisboa: Difel, 1987.

\section{DEFLEUR, Melvin L.; BALL-} ROKEACH, Sandra. Teorias da comunicação de massa. Rio de Janeiro: Zahar, 1993.

DIDI-HUBERMAN, Georges. Diante da Imagem: questão colocada aos fins de uma história da arte. Trad. Paulo Neves. São Paulo: 34, 2013.

O que vemos, o que nos olha. Trad. Paulo Neves. São Paulo: 34, 1998.

A Pintura Encarnada.

São Paulo: Escuta, 2012
DIEGUES, Isabel; COELHO,

Frederico (Org.).

Desdobramentos da pintura brasileira séc. XXI. Rio de Janeiro: Cobogó, 2012

GAIA, Rossana. Pintores divulgam a arte e mudam campanha política. Jornal de Alagoas. Caderno Geral. Maceió, 17 de agosto de 1986

\section{JAMESON, Fredric. Pós-}

Modernismo ou Pós-

Modernidade? Conferência Fronteiras do Pensamento. Direção Camila Gonzatto e Gina O'Donnell. Produção Telos Cultural e Audiovisual Okna. Publicado em 5. Jul. 2013. 3min32s. Legendado. [extraído do Documentário Encontros e Dissonâncias] Tradução Marina Waquil e Francesco Settineri. Disponivel em:<

https://youtu.be/nSNAhib3B_M >. Acesso em 28.set. 2015.

JIMENEZ, Marc. O que é estética? São Leopoldo: Unisinos, 1999. LÉVY, Pierre. O Que é Virtual? Rio de Janeiro: Editora 34, 1996.

XXXX. Os ecos da geração 80: a pintura contemporânea em Maceió. 2016. 155 f. Dissertação (Mestrado em História) Instituto de Ciências Humanas, Comunicação e Artes, Universidade Federal de Alagoas, Maceió, 2016.

PEIRCE, Charles Sanders. Semiótica. São Paulo: Perspectiva, 2005.

PITTA, Fernanda. Limites, impasses e passagens: a história da arte em Carlo Ginzburg. In: ArtCultura: Universidade Federal de Uberlândia. Uberlândia, juldez 2007. v.9. n. 15. p. 127-143.

Disponivel em: <

http://www.artcultura.inhis.ufu.b r/PDF15/CG_Pitta.pdf

>. Acesso em: 25. jun, 2015. 
RANCIËRE, Jacques. O

inconsciente estético. São Paulo: 34, 2009.

SANTAELLA, Lucia. Matrizes da linguagem e pensamento: sonora visual verbal. São Paulo: lluminuras, 2005.

Semiótica

Aplicada. São Paulo: Pioneira

Thomson Learning, 2004.

Velloso, Monica Pimenta.

História e Modernismo. Belo

Horizonte: Autêntica, 2010.

[Coleção História \& Reflexões, $n^{\circ}$ $14]$.

VIEIRA, Débora. Permanente estado de arte. Gazeta de Alagoas. Revista Maré. ano XXXI. n. 357. Maceió, 24 maio, 2015. p. 6-7.

1 - O simbolo é tudo que pode ser aplicável a tudo o que pode concretizar a ideia ligada à palavra (PEIRCE, 2005)

2 - Importante salientar aqui também a definição de signo por Peirce, considerado o pai da Semiótica: "qualquer coisa que conduz alguma outra coisa (seu interpretante) a referir-se a um objeto ao qual ela mesma se refere (seu objeto),

de modo idêntico, transformando-se o interpretante, por sua vez, em signo, e assim sucessivamente ad infinitum" (PEIRCE, 2005,74).

Recebido em 25 jul 2019 I Aprovado em 05 dez 2019

Ana Beatriz Bezerra de MELO

Mestra em História pela Universidade Federal de Alagoas (UFAL). Professora no Centro Universitário Mauricio de Nassau (UNINASSAU-Maceió), nos cursos de Publicidade \& Propaganda e Design. Possui formação em Relações Públicas e Design de Interiores.

E-mail: anabeatriz.melo89@gmail.com 